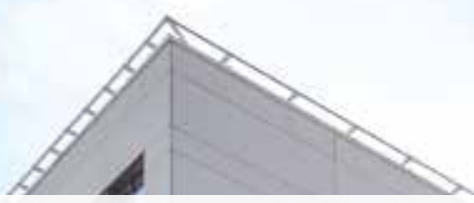

Citation: SZENTIRMAI, T. (2021) Symbolic duality: Richter Gedeon community and office building, Debrecen, Hungary

Metszet, Vol 12, No 1, pp 46-51. https://doi.org/10.33268/Met.2021.1.6

Affiliation: University of Debrecen

Received: 5 January 2021

Accepted: 16 February 2021

Published: 4 March 2021

Abstract: Due to changes in the way people work, digital technology and home office working, this office development for a pharmaceutical company has taken a change for what some may consider the absurd. Leading to the creation of an office building which supports a community space. The possibility of a future where business and community become mutually beneficial seems to be at hand, with the potential of softening the often-harsh environments created by industrial/ business parks.

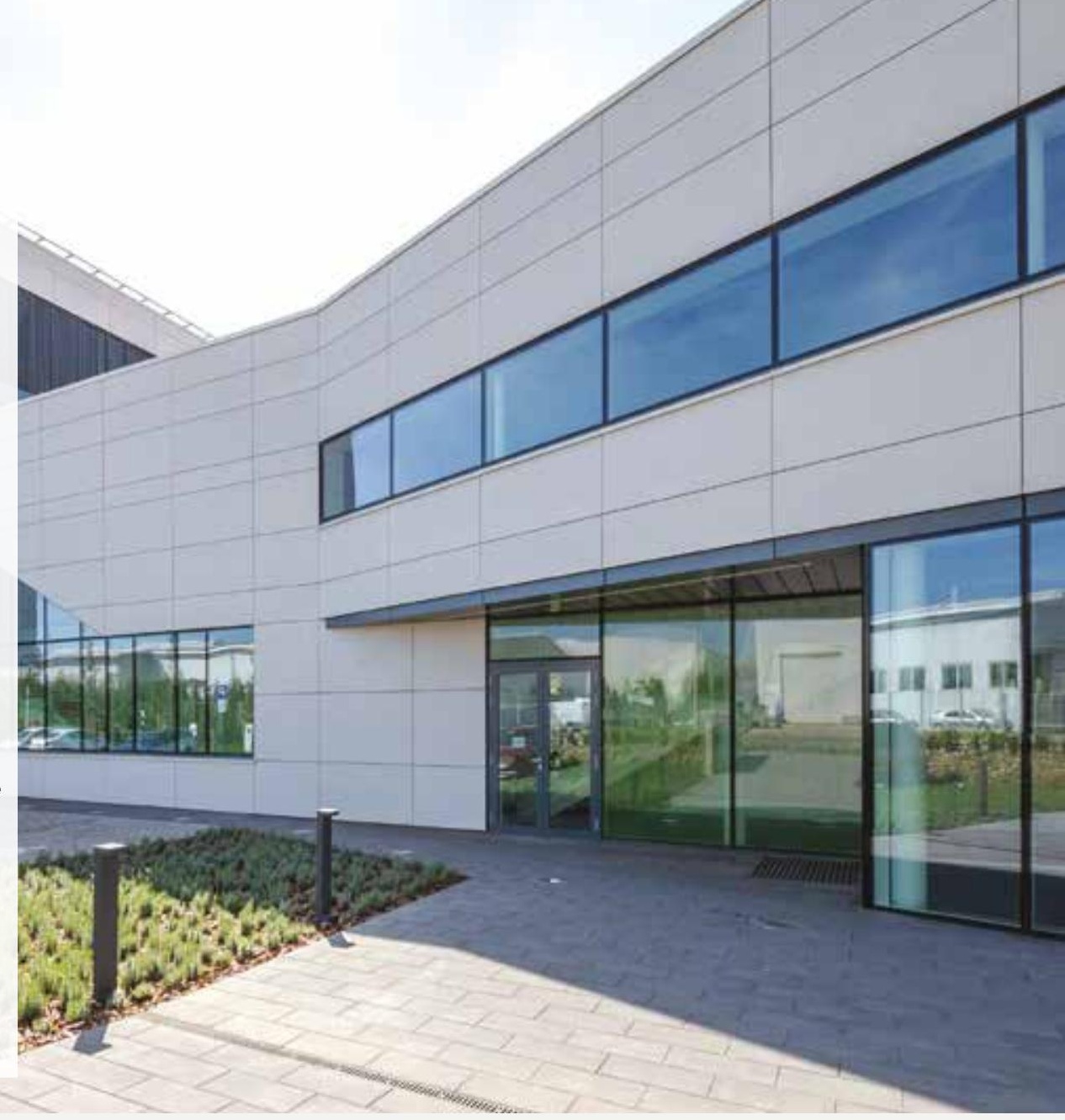

\title{
JELSZERÜ KETTŐSSÉG
}

\section{A RICHTER GEDEON ÚJ KÖZÖSSÉGI ÉS IRODAÉPÜLETE | DEBRECEN}

_Ősszel adták át a Richter Gedeon debreceni telephelyének újonnan épült közösségi és irodaépületét, melyet azóta sem tudott a gyógyszergyártó cég teljes funkcionalitásában kihasználni, ezzel is jól mutatva a jelenlegi helyzet abszurdba hajlását. Egyben rávilágítva, hogy az elmúlt időszak digitális átállása, az otthonról való munkavégzés térhódítása nyomán megkerülhetetlen az irodai funkció újraértelmezése.

_ Habár lakosságszámát tekintve Debrecen a főváros után jelentősen lemaradva a második legnagyobb város az országban, területe mégis majdnem megegyezik Budapest területével, [I] ami mezővárosi gyökeréből eredeztethető. Ez a történeti adottság mind a mai napig meghatározza a város szerkezetét, a városfejlődés lehetőségeit, irányait. [2] A fejlődés a belvárostól kifelé, koncentrikusan történt, és az elmúlt évtizedek nagyarányú ipari és kereskedelmi fejlesztései is a városból kivezető fő közlekedési utak mentén, nagyjából azonos körben helyezkednek el. A Richter Gedeon biotechnológiai üzemének helyet adó Határ úti ipari park az egykori téglagyár területén található, a belvárostól messze, a város szélén, a városnyi méretű tócóskerti lakótelep és egy új építésű, családi házas lakóövezetet követően.

__ A jelentős gazdasági fejlesztések következtében lényegesen növekedett az ipari parkok száma és területe a városban az elmúlt időszakban. Ezek közül jelenleg a Határ úti a legnagyobb, melynek egyik kiemelt szereplője a bő tíz éve jelen lévő Richter Gedeon Vegyészeti Gyár debreceni fióktelepe. A kiemelt szerep különösen igaz építészeti szempontból, hiszen az ipari parkok általános sablonépítészete mellett 


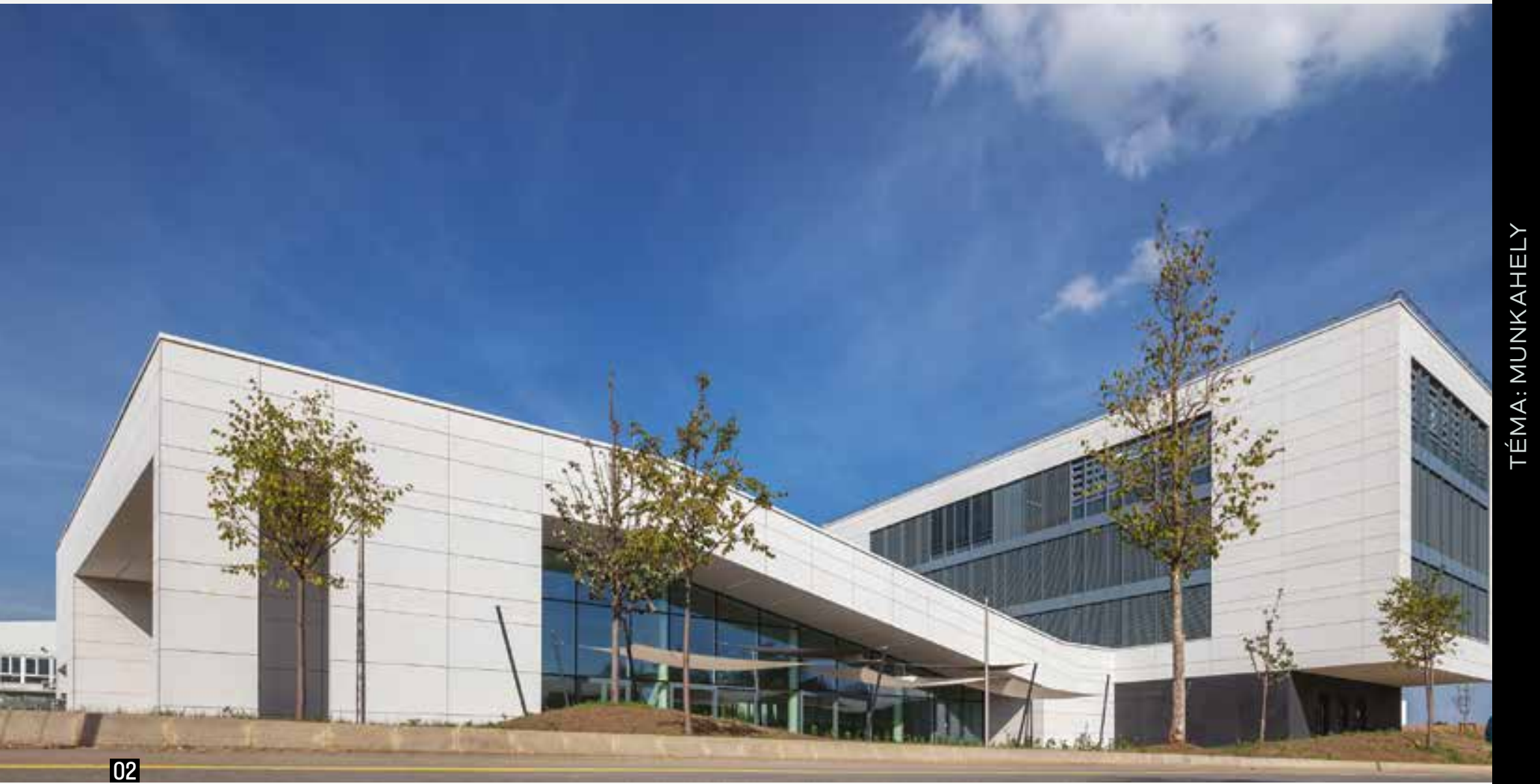

01 A megérkezés hangsúlyos eleme a konzolos irodatömb

02 Nagy üvegfelülettel nyit a telep belseje felé a közösségi szint

ÉPÍTÉSZ | ARCHITECT

Töös György, Szökedenesi Géza
SZERZŐ | AUTHOR

Szentirmai Tamás
FOTÓ | PHOTO

Bujnovszky Tamás a gyár láthatóan fontosnak tartja építészeti kialakítását, mind kereskedelmi arculata, mind a dolgozók munkakörnyezete, mind a városban betöltött gazdasági szerepe okán. Feltételezhetően részben ennek is köszönhető az egész központ átgondolt és minőségi fejlesztése, melybe az olyan funkciók is beleértendőek, mint a bejárati portaépület vagy a gyártócsarnok.

_ A Richter-központ nemcsak az ipari park építészetileg meghatározó eleme, de az Artonic müterem építészei által tervezett közösségi és ipari épület az egész park jelképévé lett. Az épület határozottan elkülönül az ipari parkot meghatározó csarnokszerkezetektől. Az irodarész modernista utalásként megemelt, konzolosan kialakított tömbje könynyedségével, eleganciájával képez kontrasztot a gyártó- és raktárépületekkel. Ez a gesztus - az ipari környezettel szembeni tiszta könnyedség - nem egyedi a kortárs irodaépítészetben. Elég csak egyik ikonikus példáját, a kínai Huai'an város egyik gyártelepéhez tartozó irodaházat [3] említeni: a vízen úszó épület lágy formájával Álvaro Siza a gyártelep disztópiáját ellenpontozza.

_ A Richter tömbje két, markánsan különböző tömegből áll össze harmonikus egységgé. A földhöz tapadó, a közösségi funkciókat magában foglaló, részben kétszintes épületrész tömegalakításával reagál a meglévő épületekre, az új funkcionális elvárásokra és a telep belső életére. Ez

01 a tömeg valóban a telep központjaként müködik, főbejáratának is a belső, fedett-nyitott, előtetős tér tekinthető, mely az utcai bejárathoz képest sokkal nagyobb, és intenzívebb 


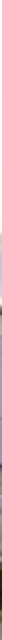

\section{A két tömeg csatlakozásán egyszerre érezhetó az összetartozás és az elválasztás szándéka, az irodarész könnyed lebegését evósiti az atektonikus módon üvegezett felületre felfekvó tömeg}

07 A munkahelyek rendezettsége és

a közösségi tér kötetlensége köszön vissza a két rész homlokzati kialakításán

08 Átlátások, világosság, fehérség jellemzi a különböző funkciók közti fő közlekedő részt, a tisztaságot, egészséget sejtetve

09

Kiemelt kapcsolati elem az épület és a telekbelső között az étterem nyitható üvegfala, a hatalmas terasz

10 Lábazati csomópont
Novartis látogatóközpontja. [4] Míg ott a pazar és fenséges [5] anyaghasználat a cég gyógyszeriparban meghatározó szerepére utalhat, addig itt a fényből, fehérségből, átlátszóságból adódóan a tisztaságot, egészséget sejtjük. Ezt a már-már éteri tisztaságot két apró belsőépítészeti - ismét a nemzetközi trendekre érzékenyen figyelő - gesztus színesíti: a szoborszerü lépcsőkarok melletti tömör falszakaszon lévő, változó textúrájú és tapintású izlandi zuzmófal a tér neutralitását oldja a természet megjelenítésével, míg a bejáratnál lévő függőlámpák elsőre véletlenszerű együttese a művészettörténetből régről ismert - és a kortárs populáris kultúrában és dizájnban is intenzíven használt - anamorfózis [6] jelenségre szép építészeti példa: a megérkezés egy adott pontjából a cég jól ismert, monogramszerü emblémájává (RG) állnak össze, tovább oldva a homogén fehér tér szigorát.

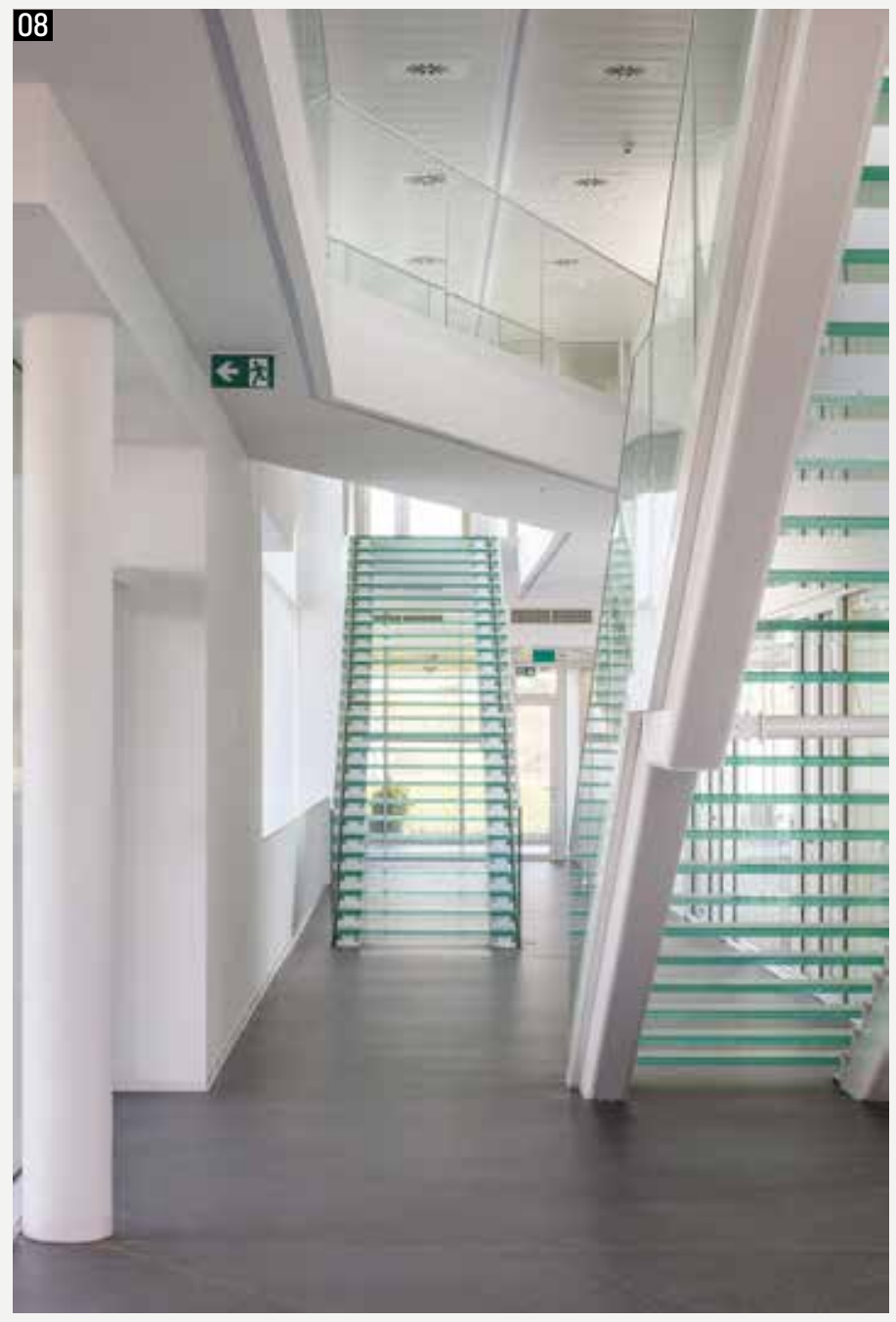


